\title{
THE INFLUENCE OF TEMPERATURE ON THE HEIGHT INCREMENT OF SCOTS PINE (PINUS SYLVESTIS L.)
}

\author{
Katarzyna Kaźmierczak, Bogna Zawieja \\ Poznań University of Life Sciences
}

\begin{abstract}
The annual height increment of Scots pine exerts a direct influence on the determination accuracy of the tree and the stand volume increment. It is considered as a major dendrometric characteristic. However, the growth of trees depends on the meteorological conditions in the year that preceded increments, as well as in the given incremental year. In this study the relationship between annual increments, and temperature was examined. For this purpose correlation coefficients between monthly temperature and mean annual height increments were designated. Next, the forward stepwise regression procedure was used. For this purpose the SAS software package was applied. On the basis of the presented research it was found that the Scots pine increments are greater when summer months, both of the pervious year and of the given vegetation season, are cooler and when March is warmer.
\end{abstract}

Key words: correlation, regression, temperature, height increments, Scots pine (Pinus sylvestris L.)

\section{INTRODUCTION}

In commercial forests of Poland Scots pine is an important tree species. Many scientists have dealt with the impact of atmospheric conditions on diameter increment of trees (radial growth). Zienkiewicz (1946) and Ermich (1953) were the first scientists who were interested in such studies in Poland. Next, the influence of climatic conditions on radial growth of trees growing in peat soils was described by Jasnowska (1977) and Zielski (1996; 1997).

Annual height increment exerts a direct influence on the determination accuracy of the stand volume increment. It is considered as a major dendrometric characteristic.

Corresponding author - Adres do korespondencji: Dr hab. Katarzyna Kaźmierczak, Department of Forest Management, Poznań University of Life Sciences, Wojska Polskiego 28, 60-637 Poznań, Poland, e-mail: kkdendro@up.poznan.pl

(C) Copyright by Wydawnictwo Uniwersytetu Przyrodniczego w Poznaniu 
Thus, it is important to study the dependences of this characteristic on weather conditions. These relationships were analysed by Kaźmierczak and Zawieja (2011) for one age group (24-year) of pine stands. In this paper, eight age groups of trees were considered.

Scots pine grows in areas, in which temperature ranges from -60 to $+40^{\circ} \mathrm{C}$. It belongs to the northern (boreal-arctic northern) and mountain tree type. The growth activity of pine covers the period from May to September in Poland. Annual shoots develop from buds formed in the previous vegetation season. The length of these increments does not change in the next vegetation season (because it lignified) and it is possible to determine its length at any given time. The length of annual shoots depends on the weather during the growth (in the vegetation year) as well as in the previous year.

The aim of the study was to determine the dependence between annual increments in length of the main shoot (annual increment in height) and meteorological conditions (temperature) in the both previous and incremental years. The eight age classes of trees are considered.

\section{EXPERIMENTAL DATA AND METHOD}

All the considered Scots pine stands were located on fresh mixed coniferous forest sites in the Zielonka Experimental Forest District. The increments in height were measured in a ten-year vegetation period (from 1989 to 1998). The sample trees were selected following the methodology developed by Draudt (Grochowski 1973). There were 25 trees selected separately from eight age classes. Consequently the experimental material included ten-year measurements of 200 Scots pine stems. The names of the considered age classes of trees refer to the age of trees in which last measurement was made. For example group 24 denotes trees which first measurement applies to trees at 15 in the ten-year period. In fact, in the study five-year periods are considered, thus, ten-year terms were divided into two five-year periods and all calculations were done separately for each of them.

The data concerning average monthly temperatures in the Zielonka forest were collected form July 1988 to September 1998. The temperatures in the months that preceded increments (formation of buds), as well as of the given vegetation season, were taken into account.

For each age group and each five-year terms Pearson's correlation coefficients between monthly temperature $\left[{ }^{\circ} \mathrm{C}\right]$ and mean annual height increments $[\mathrm{m}]$ were designated. It is interesting in which month temperature has the strongest impact on increments. For this purpose the multiple regression analysis was used. The variables (months) included in the regression model were selected on the basis Mallows' $C_{p}$ statistics (Mallows 1973) and taking into account the significance of regression coefficients. For this purpose the SAS software package was used. 


\section{RESULTS}

In Figure 1 mean annual increments of all age classes of trees in the ten-year period were given. Growth dynamics of the younger trees $(24,33)$ is more diverse than of the older ones $(72,84$, and 94). They are more susceptible to various factors than older trees. However, a similar trend can be clearly seen in the subsequent years. Thus, it can be supposed that they depend on the meteorological conditions in each year.

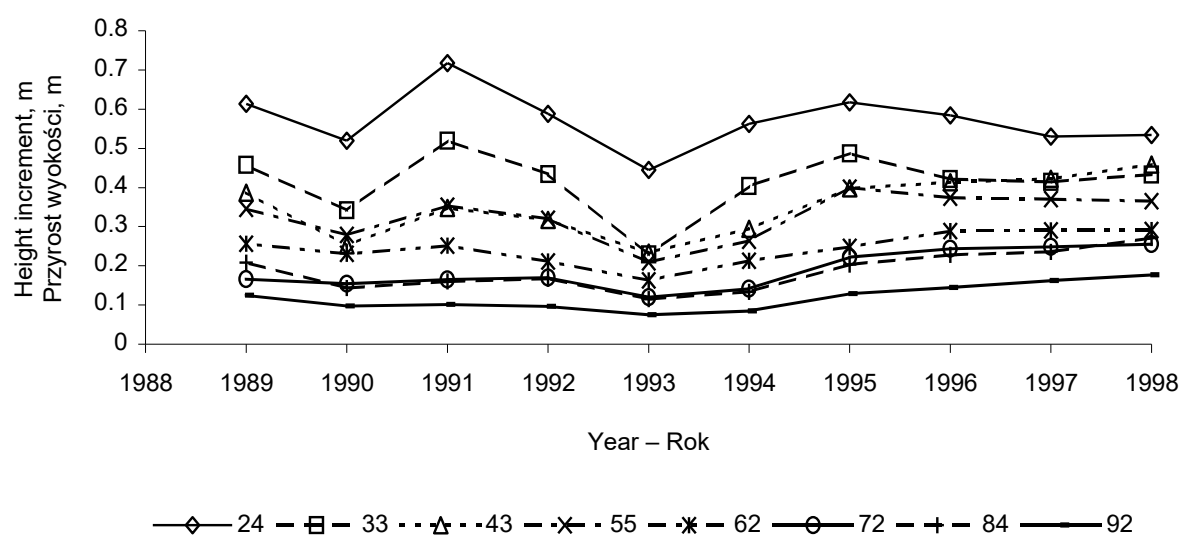

Fig. 1. Mean annual height increments of individual age classes of trees in the ten-year period (arabic numerals denote the age groups of trees)

Rys. 1. Średni roczny przyrost wysokości w klasach wieku drzew w 10-letnim okresie przyrostowym (liczby arabskie oznaczają grupy wiekowe drzew)

The mean monthly temperatures from January to June were presented in the Figure 2 and from July to December in the Figure 3. The temperatures were given for eleven years, since the preceding trees increments year was included too. It can be observed that in some months, in each of the considered years, the average temperatures were similar, but in the others they were highly variable. In the eleven-year period the smallest temperature fluctuations were in September $\left(4^{\circ} \mathrm{C}\right)$, whereas the largest in winter months, namely in February $\left(10.7^{\circ} \mathrm{C}\right)$ and January $\left(8.5^{\circ} \mathrm{C}\right)$. On the other hand, in the first six-year period the smallest temperature fluctuations were in April $\left(2.1^{\circ} \mathrm{C}\right)$, January $\left(2.6^{\circ} \mathrm{C}\right)$, while the largest in February $\left(8.9^{\circ} \mathrm{C}\right)$ and May $\left(7.1^{\circ} \mathrm{C}\right)$. In the second six-year period the smallest temperature fluctuations were in June $\left(1.8^{\circ} \mathrm{C}\right)$, whereas the largest in February $\left(9.8^{\circ} \mathrm{C}\right)$.

Correlation coefficients between average monthly temperatures and both considered five-years increments were presented in Tables 1 and 2. In order to distinguish the months that preceded vegetation season from the months during vegetation season, in the first case before the number of the month letter $p$, and in the second one letter $a$ were placed. 


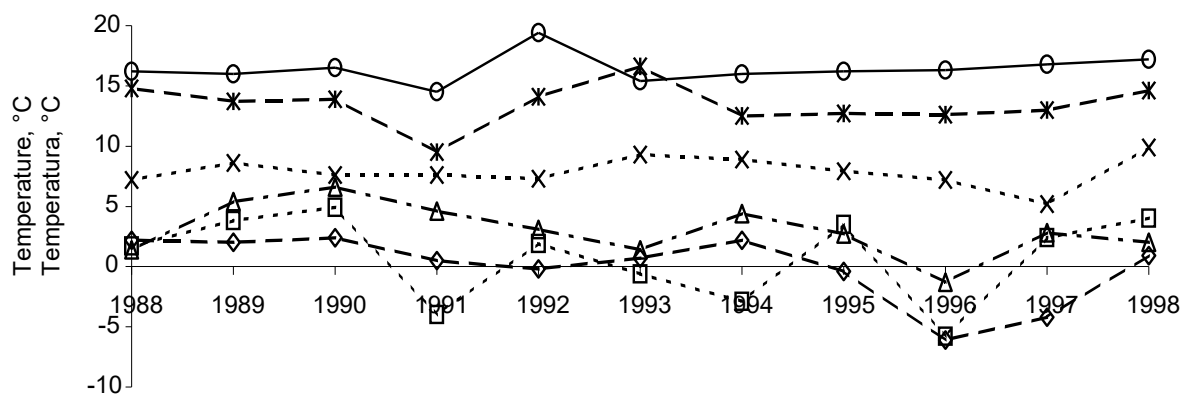

$$
\begin{aligned}
& \text { Year - Rok }
\end{aligned}
$$

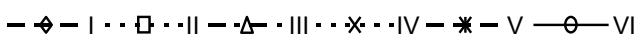

Fig. 2. Mean monthly temperatures in the first half of considered years (roman numerals indicate the months)

Rys. 2. Średnia miesięczna temperatura w pierwszej połowie roku badanych lat (liczby rzymskie oznaczają miesiące)

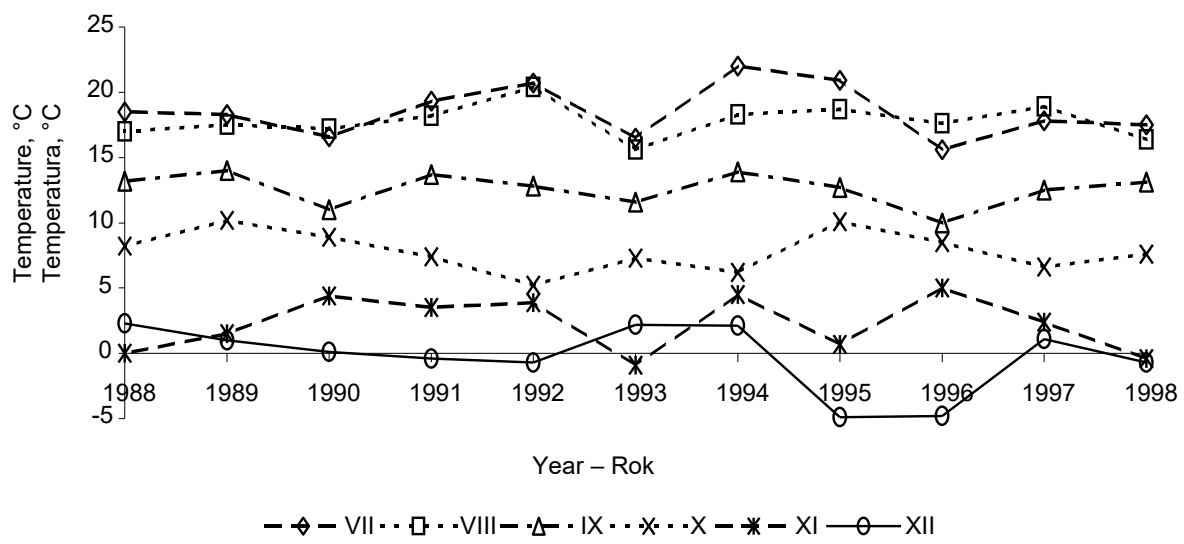

Fig. 3. Mean monthly temperatures in the second half of considered years

Rys. 3. Średnia miesięczna temperatura w drugiej połowie roku badanych lat

In both five-year periods, correlation coefficients were significant in most cases. Thus, there was some relationship between the considered factors. In the first period, strong correlations were observed in July ( $p V I I)$, August ( $p V I I I)$, March (aIII), and September $(a I X)$ for most of age groups. In the second period significant correlation coefficients were obtained mostly for trees belonging to 43, 55, 62, 72, 84 and 92 age groups. In this period the most significant correlations were obtained in August ( $p V I I I)$, January $(I)$, March (aIII), June (aVI) and July (aVII). 
Table 1. Pearson correlation coefficients and their significances between height increments of trees $[\mathrm{m}]$ and monthly average temperature $\left[{ }^{\circ} \mathrm{C}\right]$ in $1989-1993$ incremental period

Tabela 1. Współczynniki korelacji Pearsona zależności przyrostu wysokości drzew [m] od średniej miesięcznej temperatury $\left[{ }^{\circ} \mathrm{C}\right] \mathrm{w}$ okresie przyrostowym $1989-1993$

\begin{tabular}{|c|c|c|c|c|c|c|c|c|}
\hline \multirow[b]{2}{*}{$\begin{array}{l}\text { Month } \\
\text { Miesiąc }\end{array}$} & \multicolumn{8}{|c|}{$\begin{array}{l}\text { Age groups - age of trees in least increments year } \\
\text { Grupa wiekowa - wiek drzew w ostatnim roku przyrostowym }\end{array}$} \\
\hline & 19 & 28 & 38 & 50 & 57 & 67 & 79 & 87 \\
\hline$p V I I$ & -0.62 & -0.59 & -0.36 & -0.46 & -0.34 & -0.18 & -0.20 & -0.16 \\
\hline$p V I I I$ & -0.54 & -0.60 & -0.45 & -0.51 & -0.39 & -0.23 & -0.35 & -0.25 \\
\hline$p I X$ & -0.43 & -0.30 & -0.20 & -0.18 & -0.09 & -0.00 & 0.02 & 0.01 \\
\hline$p X$ & 0.34 & 0.37 & 0.18 & 0.33 & 0.32 & 0.17 & 0.17 & 0.15 \\
\hline$p X I$ & 0.05 & -0.05 & -0.20 & -0.13 & -0.19 & -0.07 & -0.28 & -0.21 \\
\hline$p X I I$ & 0.19 & 0.26 & 0.35 & 0.28 & 0.29 & 0.11 & 0.34 & 0.25 \\
\hline$a I$ & -0.14 & -0.11 & -0.03 & -0.02 & 0.15 & -0.01 & 0.09 & 0.12 \\
\hline$a I I$ & -0.28 & -0.16 & -0.05 & -0.05 & 0.05 & 0.04 & 0.14 & 0.10 \\
\hline aIII & 0.27 & 0.32 & 0.21 & 0.31 & 0.33 & 0.15 & 0.22 & 0.19 \\
\hline$a I V$ & -0.39 & -0.43 & -0.16 & -0.34 & -0.20 & -0.20 & -0.11 & -0.06 \\
\hline$a V$ & -0.66 & -0.62 & -0.37 & -0.46 & -0.30 & -0.17 & -0.17 & -0.12 \\
\hline$a V I$ & -0.11 & 0.02 & -0.01 & 0.03 & -0.06 & 0.10 & 0.08 & 0.00 \\
\hline$a V I I$ & 0.48 & 0.53 & 0.40 & 0.41 & 0.14 & 0.19 & 0.23 & 0.09 \\
\hline aVIII & 0.39 & 0.48 & 0.30 & 0.38 & 0.14 & 0.21 & 0.21 & 0.09 \\
\hline$a I X$ & 0.57 & 0.59 & 0.59 & 0.47 & 0.25 & 0.16 & 0.35 & 0.20 \\
\hline
\end{tabular}

Letter $p$ and Roman number - the month in the year that preceded incremental.

Letter $a$ and Roman number - the month in the vegetation year.

Bold font - the significance value of correlation coefficients $(\alpha=0.05)$.

Litera $p$ przed rzymskim oznaczeniem miesiąca - miesiąc roku poprzedniego.

Litera $a$ przed rzymskim oznaczeniem miesiąca - miesiąc roku przyrostowego.

Pogrubioną czcionką zaznaczono wartości istotne na poziomie $\alpha=0,05$.

In August, at the time of buds tying ( $p V I I I)$, the significant values of correlation coefficients were obtained in almost all age-group of trees. But in the first five-year increments period they were negative and in the second positive. The similar contradiction can be seen in other months. The mean temperatures concerning each considered month in five-year periods were given in Table 3 and Figure 4. In summer months (July, August, and September) in the year that preceded increments the mean temperature was higher in the first period than in the second. Warm summer did not affect the accumulation of the appropriate amount of reserve substances in buds, whereas lower temperature, 
Table 2. Pearson correlation coefficients and their significances between height increments $[\mathrm{m}]$ of trees and monthly average temperature $\left[{ }^{\circ} \mathrm{C}\right]$ in 1994-1998 incremental period

Tabela 2. Współczynniki korelacji Pearsona zależności przyrostu wysokości drzew [m] od średniej miesięcznej temperatury $\left[{ }^{\circ} \mathrm{C}\right] \mathrm{w}$ okresie przyrostowym $1994-1998$

\begin{tabular}{|c|c|c|c|c|c|c|c|c|}
\hline \multirow[b]{2}{*}{$\begin{array}{l}\text { Month } \\
\text { Miesiąc }\end{array}$} & \multicolumn{8}{|c|}{$\begin{array}{l}\text { Age groups - age of trees in least increments year } \\
\text { Grupa wiekowa - wiek drzew w ostatnim roku przyrostowym }\end{array}$} \\
\hline & 24 & 33 & 43 & 55 & 62 & 72 & 84 & 92 \\
\hline$p V I I$ & 0.21 & 0.14 & 0.09 & 0.27 & 0.01 & 0.11 & 0.06 & -0.01 \\
\hline$p V I I I$ & 0.03 & 0.09 & 0.44 & 0.42 & 0.26 & 0.46 & 0.54 & 0.43 \\
\hline$p I X$ & 0.19 & 0.15 & 0.05 & 0.17 & -0.05 & 0.02 & 0.01 & -0.06 \\
\hline$p X$ & -0.03 & -0.10 & 0.04 & 0.03 & 0.14 & 0.11 & 0.07 & 0.07 \\
\hline$p X I$ & -0.00 & 0.11 & 0.30 & 0.37 & 0.15 & 0.32 & 0.33 & 0.31 \\
\hline$p X I I$ & 0.06 & 0.08 & -0.19 & -0.17 & -0.22 & -0.27 & -0.25 & -0.24 \\
\hline$a I$ & -0.01 & 0.02 & -0.21 & -0.26 & -0.22 & -0.30 & -0.25 & -0.22 \\
\hline alI & -0.05 & 0.10 & 0.23 & 0.20 & 0.07 & 0.19 & 0.27 & 0.25 \\
\hline aIII & -0.05 & -0.01 & -0.26 & -0.26 & -0.22 & -0.31 & -0.32 & -0.24 \\
\hline$a I V$ & 0.02 & 0.02 & -0.07 & -0.16 & -0.11 & -0.15 & -0.06 & -0.10 \\
\hline$a V$ & -0.13 & 0.01 & 0.32 & 0.11 & 0.17 & 0.26 & 0.44 & 0.37 \\
\hline$a V I$ & -0.17 & -0.01 & 0.39 & 0.19 & 0.25 & 0.37 & 0.53 & 0.47 \\
\hline$a V I I$ & 0.07 & 0.04 & -0.36 & -0.25 & -0.30 & -0.41 & -0.47 & -0.40 \\
\hline$a V I I I$ & 0.07 & 0.02 & -0.22 & -0.01 & -0.13 & -0.17 & -0.32 & -0.23 \\
\hline$a I X$ & -0.07 & -0.00 & -0.20 & -0.25 & -0.19 & -0.27 & -0.23 & -0.17 \\
\hline
\end{tabular}

Explanation as in Table 1.

Objaśnienia jak w tabeli 1.

especially in August, affected the larger increments in next year. Moreover, in the incremental year (in table month designated as $a V I I-a I X$ ) there was an opposite situation. In the first period the correlation coefficients were positive and in the second one were negative (except younger trees). In Figure 4 and Table 3 it was shown that mean temperature in the first period was lower than in the second one. Thus in both periods in the time of tying buds and growth of trees the lower temperature was more favourable in summer months. In the first considered period the mean temperature in March was higher than in the second period and in first period the correlation coefficients were positive. Warmer March contributed to the early start of the growing season and also extended to the term of tree growth. But warm April in the first period had a negative influence on the increments. 


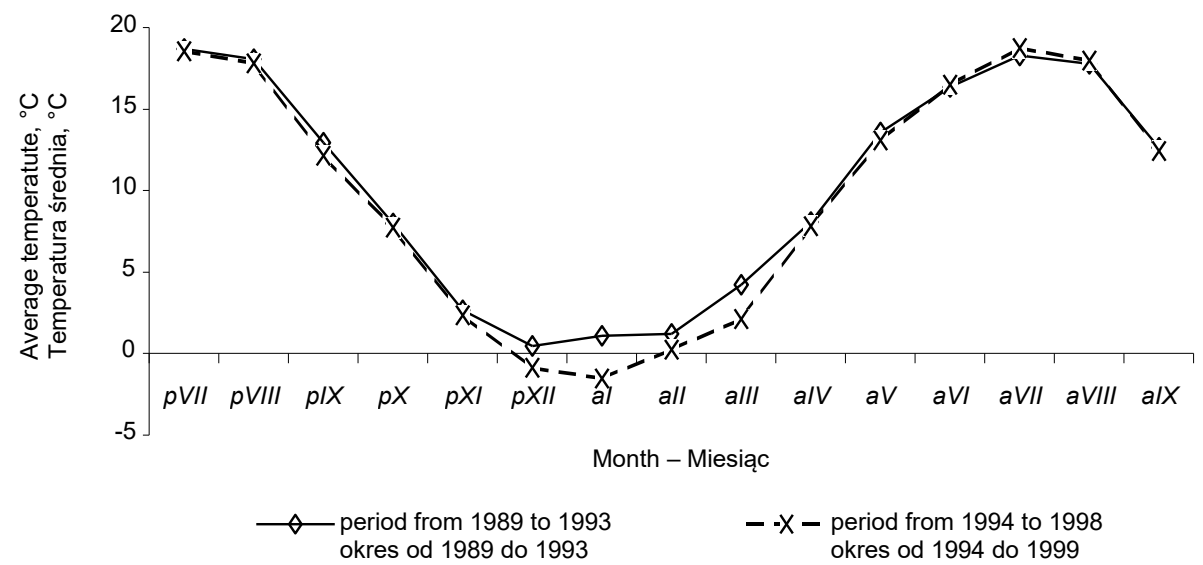

Fig. 4. Monthly average temperatures in five-year periods

Rys. 4. Średnia miesięczna temperatura w 5-letnich okresach przyrostowych

Table 3. Monthly average temperatures $\left[{ }^{\circ} \mathrm{C}\right]$ in five-year periods

Tabela 3. Średnia miesięczna temperatura $\left[{ }^{\circ} \mathrm{C}\right]$ w 5 -letnich okresach przyrostowych

\begin{tabular}{ccccccccc}
\hline $\begin{array}{c}\text { Period } \\
\text { Okres }\end{array}$ & $p V I I$ & $p V I I I$ & $P I X$ & $p X$ & $p X I$ & $p X I I$ & $a I$ & $a I I$ \\
\hline $1989-1993$ & 18.7 & 18.1 & 12.9 & 7.98 & 2.66 & 0.46 & 1.08 & 1.2 \\
$1994-1998$ & 18.6 & 17.8 & 12.1 & 7.74 & 2.34 & -0.9 & -1.5 & 0.24 \\
\hline $\begin{array}{c}\text { Period } \\
\text { Okres }\end{array}$ & aIII & aIV & $a V$ & $a V I$ & aVII & aVIII & aIX & \\
\hline $1989-1993$ & 4.22 & 8.08 & 13.6 & 16.4 & 18.3 & 17.8 & 12.6 & \\
$1994-1998$ & 2.12 & 7.82 & 13.1 & 16.5 & 18.8 & 18 & 12.4 & \\
\hline
\end{tabular}

Due to the fact that many of the correlation coefficients obtained a significant value, in order to find months that had significant impact on increments in the particular age groups, the model analysis of regression was selected using Mallows' $C_{p}$ statistic (Mallows, 1973). When in the model with the smallest $C_{p}$ one of the regression coefficient occurs negligible then the model with greater $C_{p}$ was selected. The effects of analysis of regression in the first period are presented in Table 4 and in the second period in Table 5.

In the first period the biggest impact on increments was noted in August of the year that preceded increments. In the second period it was noted in July and August of the year that preceded increments. The results are similar to those obtained from correlation coefficients. In the second period for tree from 33 age group the model of regression with small $C_{p}(<p$, where $p$ is the number used explanatory variables) and all significant coefficients cannot be selected. 
Table 4. Regression coefficients of dependences between average height increments and average monthly temperatures in 1989-1993 incremental period

Tabela 4. Współczynniki korelacji między średnim przyrostem wysokości drzew i średnią miesięczną temperaturą w okresie przyrostowym 1989-1993

\begin{tabular}{|c|c|c|c|c|c|c|c|c|c|c|}
\hline $\begin{array}{l}\text { Age groups } \\
\text { Grupa } \\
\text { wiekowa }\end{array}$ & & & & $\begin{array}{l}\text { Equati } \\
\text { Rów }\end{array}$ & $\begin{array}{l}\text { ons } \\
\text { unan }\end{array}$ & $\begin{array}{l}\text { of regressic } \\
\text { ie regresji }\end{array}$ & & & & $C_{p}$ \\
\hline 19 & 0.55625 & - & 0.02818 & $a V$ & + & 0.03190 & $a I X$ & & & 2.9900 \\
\hline $\begin{array}{l}p \text {-value } \\
p \text {-wartość }\end{array}$ & 0.0005 & & $<.0001$ & & & 0.0005 & & & & \\
\hline 28 & 4.67734 & - & 0.27834 & $p V I I$ & - & 0.16354 & $p I X$ & - 0.15014 & $p X$ & 3.0106 \\
\hline $\begin{array}{l}p \text {-value } \\
p \text {-wartość }\end{array}$ & $<.0001$ & & $<.0001$ & & & $<.0001$ & & $<.0001$ & & \\
\hline 38 & 2.23440 & - & 0.08646 & $p V I I I$ & - & 0.04580 & $p X$ & & & 1.4260 \\
\hline $\begin{array}{l}p \text {-value } \\
p \text {-wartość }\end{array}$ & $<.0001$ & & $<.0001$ & & & $<.0001$ & & & & \\
\hline 50 & 1.69617 & - & 0.07112 & $p V I I I$ & - & 0.02613 & aIII & & & 1.0069 \\
\hline $\begin{array}{l}p \text {-value } \\
p \text {-wartość }\end{array}$ & $<.0001$ & & $<.0001$ & & & 0.0006 & & & & \\
\hline 57 & 0.70796 & - & 0.02687 & $p V I I I$ & & & & & & -0.2854 \\
\hline $\begin{array}{l}p \text {-value } \\
p \text {-wartość }\end{array}$ & $<.0001$ & & $<.0001$ & & & & & & & \\
\hline 67 & 0.39179 & - & 0.01311 & $p V I I I$ & & & & & & 0.9427 \\
\hline $\begin{array}{l}p \text {-value } \\
p \text {-wartość }\end{array}$ & $<.0001$ & & 0.0107 & & & & & & & \\
\hline 79 & 0.17371 & + & 0.04446 & $p X I I$ & - & 0.03267 & $a I$ & & & 1.3904 \\
\hline $\begin{array}{l}p \text {-value } \\
p \text {-wartość }\end{array}$ & $<.0001$ & & $<.0001$ & & & 0.0006 & & & & \\
\hline 87 & 0.09282 & + & 0.01279 & $p X I I$ & & & & & & 1.3222 \\
\hline $\begin{array}{l}p \text {-value } \\
p \text {-wartość }\end{array}$ & $<.0001$ & & 0.0054 & & & & & & & \\
\hline
\end{tabular}

On the basis of the received results it can be concluded that in the year that preceded the analysed incremental season, the temperature in August was the most meaningful for the length of increments of 38,50,57,67 age groups of trees in the first five-year period and 43, 55, 72, 84 in the second five-year period. Comparing the received results with fluctuations of monthly temperature (given in Figure 2 and 3 ) it can be concluded that in months in which the temperatures had greater impact on increments the fluctuations of temperatures was medium and low. 
Table 5. Regression coefficients of dependences of average height increments from average monthly temperatures in 1994-1998 incrementals period

Tabela 5. Współczynniki regresji zależności średniego przyrostu wysokości drzew od średniej miesięcznej temperatury w okresie przyrostowym 1994-1998

\begin{tabular}{|c|c|c|c|c|c|c|c|c|c|}
\hline $\begin{array}{c}\text { Age groups } \\
\text { Grupa wiekowa }\end{array}$ & & & & $\begin{array}{l}\text { Equations } \\
\text { Równar }\end{array}$ & $\begin{array}{l}\text { regressi } \\
\text { regresji }\end{array}$ & & & & $C_{p}<p$ \\
\hline 24 & & 0.35322 & + & 0.01144 & $p V I I$ & & & & 0.6026 \\
\hline $\begin{array}{l}p \text {-value } \\
p \text {-wartość }\end{array}$ & & 0.0002 & & 0.0195 & & & & & \\
\hline 33 & & 0.22413 & + & 0.01709 & $p I X$ & & & & 0.8912 \\
\hline $\begin{array}{l}p \text {-value } \\
p \text {-wartość }\end{array}$ & & 0.0820 & & 0.1051 & & & & & \\
\hline 43 & - & 0.37394 & - & 0.00981 & $p V I I$ & + & 0.05348 & $p V I I I$ & 1.5530 \\
\hline $\begin{array}{l}p \text {-value } \\
p \text {-wartość }\end{array}$ & & 0.0070 & & 0.0267 & & & $<.0001$ & & \\
\hline 55 & - & 0.92070 & + & 0.04443 & $p V I I I$ & + & 0.04443 & aVIII & 1.4356 \\
\hline $\begin{array}{l}p \text {-value } \\
p \text {-wartość }\end{array}$ & & 0.0008 & & $<.0001$ & & & 0.0074 & & \\
\hline 62 & & 0.51343 & + & 0.00319 & aII & - & 0.01321 & $a V I I$ & \\
\hline $\begin{array}{l}p \text {-value } \\
p \text {-wartość }\end{array}$ & & $<.0001$ & & 0.1380 & & & 0.0003 & & \\
\hline 72 & - & 0.29201 & + & 0.03869 & $p V I I I$ & & 0.01443 & $p I X$ & 1.4816 \\
\hline $\begin{array}{l}p \text {-value } \\
p \text {-wartość }\end{array}$ & & 0.0039 & & $<.0001$ & & & 0.0108 & & \\
\hline 84 & - & 0.40996 & - & 0.01023 & $p V I I$ & + & 0.04568 & $p V I I I$ & 1.0859 \\
\hline $\begin{array}{l}p \text {-value } \\
p \text {-wartość }\end{array}$ & & $<.0001$ & & 0.0002 & & & $<.0001$ & & \\
\hline 92 & & 0.36626 & + & 0.00540 & $a I I$ & - & 0.01217 & $a V I I$ & 1.0855 \\
\hline $\begin{array}{l}p \text {-value } \\
p \text {-wartość }\end{array}$ & & $<.0001$ & & $<.0001$ & & & $<.0001$ & & \\
\hline
\end{tabular}

In the next step it was observed that the relationship between annual height increments and ranges of annual temperatures (designated separately for each considered year) in the vegetation season were noted. In Figure 5 these quantities were presented. The ranges of annual temperatures had a similar course as the height increments. Significant value of coefficients of correlation between height increments and ranges of annual temperatures were designated by bold font in Table 6 . In the second period the negative quantities of correlation coefficients mean that if scattering of average monthly 
a

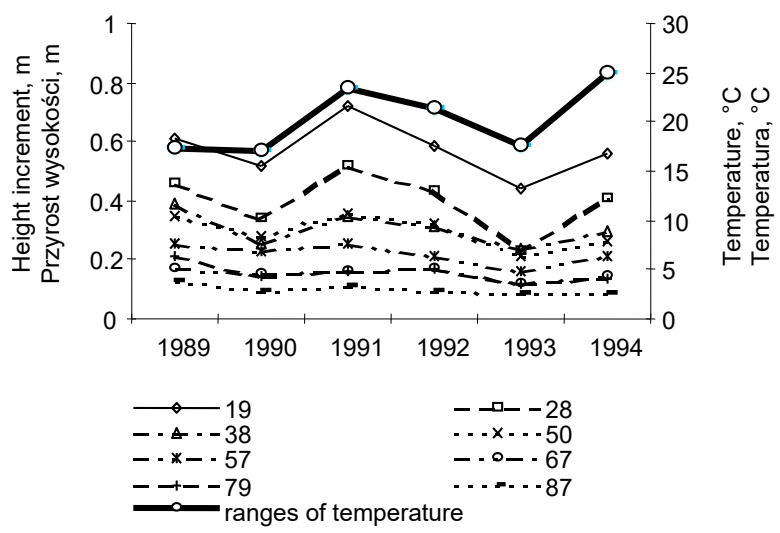

b

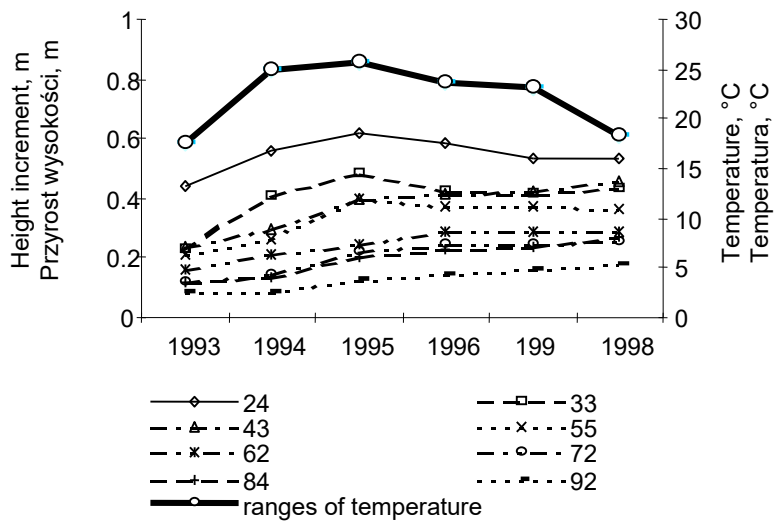

Fig. 5. Dependences average annual height increments on ranges of annual temperatures: $a$ - first period, $b-$ second period

Rys. 5. Zależność średniego rocznego przyrostu wysokości od rocznej temperatury: a - pierwszy okres przyrostowy, $\mathrm{b}$ - drugi okres przyrostowy

temperatures was large, the increments of trees were smaller. In the second period ranges of annual temperature were greater than in first one. In the first period there was no relationship in the case of oldest trees. 
Table 6. Correlation coefficients and their significances between height increments $[\mathrm{m}]$ of trees and standard deviations of annual temperatures $\left[{ }^{\circ} \mathrm{C}\right]$

Tabela 6. Współczynniki korelacji zależności przyrostu wysokości drzew [m] od odchylenia standardowego rocznej temperatury $\left[{ }^{\circ} \mathrm{C}\right]$

\begin{tabular}{lcccccccc}
\hline & \multicolumn{7}{c}{ Age groups - age of trees in least increments year } \\
& 19 & 28 & 38 & 50 & 57 & 67 & 79 & 87 \\
\hline $\begin{array}{l}\text { Period I } \\
\text { Okres I }\end{array}$ & $\mathbf{0 . 5 3}$ & $\mathbf{0 . 4 8}$ & $\mathbf{0 . 2 5}$ & $\mathbf{0 . 3 2}$ & 0.10 & 0.13 & 0.04 & -0.00 \\
\hline $1989-1993$ & \multicolumn{7}{c}{$\begin{array}{c}\text { Age groups - age of trees in least increments year } \\
\text { Grupa wiekowa - wiek drzew w ostatnim roku przyrostowym }\end{array}$} \\
\hline $\begin{array}{l}\text { Period II } \\
\text { Okres II }\end{array}$ & 24 & 33 & 43 & 55 & 62 & 72 & 84 & 92 \\
\hline $1994-1998$ & 0.17 & 0.04 & $\mathbf{- 0 . 3 1}$ & -0.07 & $\mathbf{- 0 . 2 0}$ & $-\mathbf{- 0 . 2 7}$ & $\mathbf{- 0 . 4 5}$ & $\mathbf{- 0 . 3 8}$ \\
\hline
\end{tabular}

\section{DISCUSSION AND CONCLUSIONS}

In the study of Cedro (2001) the author investigated the effect of temperature and precipitation on increments in diameter of Scots pine. She recorded that high temperature in September had a negative effect on increments. It was also stated that variation of the temperature throughout the year (ranges) had an effect on increments. Similar dependences in the case of height increment can be observed in this study. A strong relationship between mean temperature in June and August in the preceding year and the length of the apical shoot in 20-year old pines was shown by Junttila and Heide (1981). Michalak (1977) investigated the course of the diurnal increment in height in a 3-year period depending on variable meteorological conditions in the vegetation season in pine, fir, spruce, larch, oak and beech. In the paper by Zielski (1996) the significant correlation between the temperature and diameter increments of pine in the February and March was concluded. The results obtained for the pine from the Dąbrowa Tarnowska forest areas by Feliksik 1988 are similar. Namely, increments in width of the wood were strongly dependent on temperature (from January to March). Oleksyn et al. (1993) concluded that there is a significant relationship between the radial growth and winter temperatures. The formation of wide annual rings favours warm and short winters and wet and warm summers, while the frosty and long winters and dry and hot summers cause a reduction of increments, as concluded by Wilczyński (2004).

On the basis of the conducted calculations it can be possible to draw the following conclusions.

- The temperature of months from July to September in the years that preceded increments has large influence on increments in next year. 
- In spring and summer the temperature in the vegetation year has got a large influence on increments in the given year.

- Increments of trees are greater if summer is cooler and March is warmer.

- Small differences between maximum and minimum month average temperatures are favourable for bigger increments of height.

As it was shown, the temperature, especially in summer (both preceding and given increments years) and spring months, has a major impact on the growth of Scots pine. But besides other metrological conditions, it also has an influence on the increments.

\section{REFERENCES}

Assmann, E. (1968). Nauka o produkcyjności lasu [Science on forest productivity]. Warszawa: PWRiL [in Polish].

Cedro, A. (2001). Dependence of radial growth of Pinus sylvestris L. from western Pomerania on the rainfall and temperature conditions. Geochronometria, 20, 69-74.

Ermich, K. (1953). Wpływ czynników klimatycznych na przyrost dębu szypułkowego i sosny zwyczajnej. Próba analizy zagadnienia [The influence of climatic conditions on Quercus robur and Pinus sylvestris growth]. Pr. Roln.-Leśn. PAU, 68, 1-61 [in Polish].

Feliksik, E. (1988). Badania wpływu klimatu na szerokość przyrostów rocznych drewna sosny pospolitej [Investigation of the effect of climate on the width of annual rings of Scots pine wood]. Zesz. Nauk. AT-R Bydg., 158, Rolnictwo, 27, 11-17 [in Polish].

Grochowski, J. (1973). Dendrometria [Forest mensuration]. Warszawa: PWRiL [in Polish].

Jasnowska, J. (1977). Czynniki wpływające na rozmiary słojów rocznych drewna sosny na torfowisku wysokim w zespole Vaccinio uliginosi-pinetum [Influence of some factors on width of annual rings of pinus growing on the peat bog in Vaccino uliginosi-pinetum plants]. Rocz. Dendr., 30, 5-33 [in Polish].

Junttila, O., Heide, O. M. (1981). Shoot and needle growth in Pinus sylvestris as related to temperature in northern Fennoscandia. For. Sci., 27, 423-430.

Kaźmierczak, K., Zawieja, B. (2011). Dependence of height increment on the precipitations and temperature conditions in a 24-year pine stand. Colloq. Biometr., 41, 229-240.

Mallows, C. L. (1973). Some coments on CP. Technometrics, 15(4), 661-675. DOI:10.2307/ 1267380

Michalak, K. (1977). Rytmika przyrostu wysokości w okresie wegetacji ważniejszych gatunków drzew leśnych i jej zależność od elementów meteorologicznych [The rhythm of increment in height during vegetation of major forest tree species and its dependence on meteorological elements]. Zesz. Nauk. SGGW, Leśn., 25, 19-44 [in Polish].

Oleksyn, J., Fritts H. C., Hughes, M. K. (1993). Tree-ring analysis of different Pinus sylvestris provenans, Quercus robur, Larix deciduas and L. deciduas $\times$ L. kaempferi affected by air pollution. Arbor. Kórn., 38, 87-111.

Wilczyński, S. (2004). Lata „wskaźnikowe” i „wyjątkowe” w ocenie związków „przyrost radialny-klimat" [The pointer and exceptional years in assessment of relationhips ,radial growth-climate"]. Sylwan, 5, 30-40 [in Polish].

Zielski, A. (1996). Wpływ temperatury i opadów na szerokość słojów rocznych drewna u sosny zwyczajnej (Pinus sylvestris L.) w rejonie Torunia [The influence of temperature and precipitation on width of annual rings of pine (Pinus sylvestris L.)]. Sylwan, 2, 71-79 [in Polish]. 
Zielski, A. (1997). Uwarunkowania środowiskowe przyrostów radialnych sosny zwyczajnej (Pinus sylvestris L.) w Polsce Północnej na podstawie wielowiekowej chronologii [Environmental conditions of radial growth of Pinus sylvestris from North Poland on the basis of long time chronology]. Toruń: Wyd. UMK [in Polish].

Zienkiewicz, W. (1946). Badania nad wartością rocznego przyrostu drzew dla studiów wahań klimatycznych [Investigations on annual growth of trees for studies of climatic changes]. Ann. Univ. Mariae Curie-Sklodowska, 1, 177-234 [in Polish].

\section{WPLYW TEMPERATURY NA PRZYROST WYSOKOŚCI SOSNY}

Streszczenie. Przyrost wysokości należy do ważniejszych cech dendrometrycznych. Znajomość jego wielkości wpływa na dokładność ustalania przyrostu miąższości drzewa i drzewostanu. Przyrost drzew zależy od warunków meteorologicznych zarówno roku poprzedniego, jak i roku przyrostowego. W pracy badano związki temperatury z rocznym przyrostem wysokości. Zastosowano procedurę regresji krokowej, wykorzystując pakiet statystyczny SAS. Stwierdzono pozytywny wpływ niższej temperatury miesięcy letnich roku poprzedniego i przyrostowego oraz cieplejszego marca.

Slowa kluczowe: korelacja, regresja, temperatura, przyrost wysokości, Pinus sylvestris L.

Accepted for print - Zaakceptowano do druku: 18.11.2015

For citation - Do cytowania: Kaźmierczak, K., Zawieja, B. (2015). The influence of temperature on the height increment of Scots pine (Pinus sylvestis L.). Acta Sci. Pol. Silv. Colendar. Rat. Ind. Lignar., 14(3), 213-225. DOI: 10.17306/J.AFW.2015.3.19 